Acta Theriologica 41 (1): 93-105, 1996.

PL ISSN 0001-7051

\title{
Physical condition of red deer in a high density population
}

\author{
Ryszard DZIĘCIOŁOWSKI, Joanna BABIŃSKA-WERKA, \\ Michał WASILEWSKI and Jacek GOSZCZYŃSKI
}

\begin{abstract}
Dzięciołowski R., Babińska-Werka J., Wasilewski M. and Goszczyński J. 1996. Physical condition of red deer in a high density population. Acta Theriologica 41: 93-105.

Physical condition in a living at high density (120 individuals/1000 ha of forest area) red deer Cervus elaphus Linnaeus, 1758 population was studied by determining: dressed body weight, kidney fat index (KFI) and amount of visceral fat in 628 animals. Antler weights were also considered as condition index of stags. The mean body weight of calves of both sexes was identical, ie $38.0 \mathrm{~kg}$, that of hinds fluctuated from 57.8 to $75.1 \mathrm{~kg}$, stags - from 63.2 to $132.4 \mathrm{~kg}$ depending upon age. The KFI value for female and male calves, hinds, and stags at various age amounted respectively to: $1.54,1.36$, $1.60-1.76$, and $1.17-2.69$. Per cent of individuals with great amount of visceral fat amounted: in female calves - to 39.4 , in male calves - 33.3, in hinds - 47.6-66.7, and in stags $-20.0-100.0 \%$ depending upon age. Maximum weight of antlers was $4.2 \mathrm{~kg}$. Despite high population density animals indicated generally good physical condition. Except that the condition of calves of both sexes has been maintained at a similar level, what evidenced an inferior condition of males during their growth. Males in contrast to females, reveal serious decline of condition following the rut, during autumn and winter. It was related to stag age and most marked in the animals of the oldest age-classes (no less than by $40 \%$ ). Factors affecting the condition of red deer in their population from the Słowiński National Park were discussed.
\end{abstract}

Department of Forest Zoology and Wildlife Management, Agricultural University SGGW, Rakowiecka 26/30, 02-528 Warsaw, Poland

Key words: Cervus elaphus, physical condition, body weight, KFI, visceral fat, seasonal changes

\section{Introduction}

Red deer Cervus elaphus Linnaeus, 1758 population from northern Poland (Słowiński National Park) is characteristic by its very high densities. In 1990 we estimated the population of 580 individuals occupying 5028 ha of forest area (Dzięciołowski et al. 1995a). The resulting density of 120 red deer per 1000 ha of forest area was 3 to 4 times as high as the highest recorded density in Poland (Pielowski et al. 1993) and, as far as we know, in continental Europe for that matter. And so, it was 2-3 times higher than that in Belgium (Bertouille and de Crombrugghe 1995) and close to average density of red deer in Scottish hill-land (Mitchell and Crisp 1981, Ratcliffe 1984). 
During 1991 and 1992 the Słowiński National Park (SNP) red deer population was subjected to heavy culling. Despite considerable harvest in the course of two first years we did not found any effect of intensive culling upon dynamics of red deer numbers (Dzięciołowski et al. 1995a). One should expect that the deer from dense population will indicate low condition indices. Such phenomena had been recorded in deer populations living under excessive density.

Evidence of density-dependent body size and physical condition is numerous in deer family. For the red deer such evidence was demonstrated by Mitchell and Crisp (1981), Mitchell et al. (1981), Albon et al. (1983), Mitchell et al. (1986), Clutton-Brock et al. (1987), while for the white-tailed deer by Cheatum and Severinghtaus (1950), Mc Callough (1979), Teer (1984), and Shea et al. (1992). The latter found, however, that physiological indices of deer may not be sensitive to changes in population density. Mitchell and Crisp (1981) examined red deer culled as a result of shot-out of very high density population. About half of the total population was eliminated during the first season and half the remainder during next season. They found that animals showed no improvements in performance following their reduction. On the other hand, Bobek et al. (1992) found significant decline in red deer antler's weight connected with increased population density. For the roe deer, Vincent et al. (1995) found that during years of high population density the body weight of adult males dropped by ca $6 \%$ and that of juvenile individuals - by ca $20 \%$ when compared to years of lower population numbers.

The purpose of studies was to understand the performance of a red deer $C$. elaphus population living at high density. Condition indices, such as body weight, amount of kidney and visceral fat, as well as the weight of antlers, were instrumental in these studies.

\section{Study area}

Studies were carried out in the SNP $\left(54^{\circ} 33^{\prime} \mathrm{N}, 17^{\circ} 46^{\prime} \mathrm{E}\right)$ situated on the Baltic Sea coast. The park was declared by UNESCO in 1977 as a part of the international network of Biosphere reserves. The total area of the park amounts to $18247 \mathrm{ha}$, out of which more than $50 \%$ is under freshwater.

Forests in the park form several patches and a continuous belt along the seacost. The distribution of forest site types within the park is following: fresh coniferous forest $-39.2 \%$ of area, moist coniferous forest $-17.7 \%$, dry coniferous forest $-10.6 \%$, and fresh mixed coniferous forest $9.7 \%$. The remaining $11 \%$ consists of small patches of moist deciduous forest, alderwood, bog coniferous forest, etc.

Besides of forest, park has a considerable acreage of reeds and bank shrubs, which, sinilarly to woods, provide the red deer with day-time shelters. The grassy areas (meadows and pastures) adjacent to woods and reeds substantially improve feeding conditions for deer in the park. Fesides of red deer, the park is inhabited by rather numerous roe deer Capreolus capreolus and wild soar Sus scrofa populations, and a transient moose Alces alces. A more detailed description of the stidy area was given by Dzięciołowski et al. (1995b). 


\section{Material and methods}

Altogether 628 red deer were culled during 1990-1995 in the SNP. Condition of each individual had been assessed with the aid of three indices: body weight, kidney fat, and visceral fat. The body weight is easily available and depicts well any changes in physical condition (Dzięciołowski 1970, Buchli 1979, Albon et al. 1983, Bertouille and de Crombrugghe 1995). Other broadly used indexes are fat reserves, especially kidney fat (Franzmann 1992, Shea et al. 1992). Antler weights were additionally considered as an index of condition in stags.

Body weights were assessed to $0.5 \mathrm{~kg}$ for a cleaned (eviscerated) carcass with head and legs. Stags were weighed without heads. The left kidney with surrounding fat has been taken out of the carcass. Perinephric fat at the posterior and anterior ends of the kidney was cut tangentially as described by Buchli (1979). The kidney with the surrounding fat was then weighed with the accuracy to $1 \mathrm{~g}$. The perinephric fat was afterwards peeled off and the cleaned kidney was weighed again. The kidney fat index (KFI) was expressed by the following formula: KFI = mass of kidney with fat in g/mass of kidney without fat in $\mathrm{g}$. Amount of visceral fat had been appraised subjectively and assigned to one of the following categories: lack of fat, slight amount of fat, and abundant fat. Antlers were weighed with the accuracy to $0.1 \mathrm{~kg}$.

Body weight was ascertained for $628, \mathrm{KFI}$ - for 543 and visceral fat - for 623 red deer individuals. Antler weight was determined for 113 stags. Age of 628 red deer was appraised according to annual rings in the first molar (modified technique of Mitchell 1967).

\section{Results}

\section{Dressed body weights}

Among the age and sex categories identified, male and female calves ( 0.5 years old) had the same body weights (Fig. 1). Sexual dimorphism was marked in 1.5

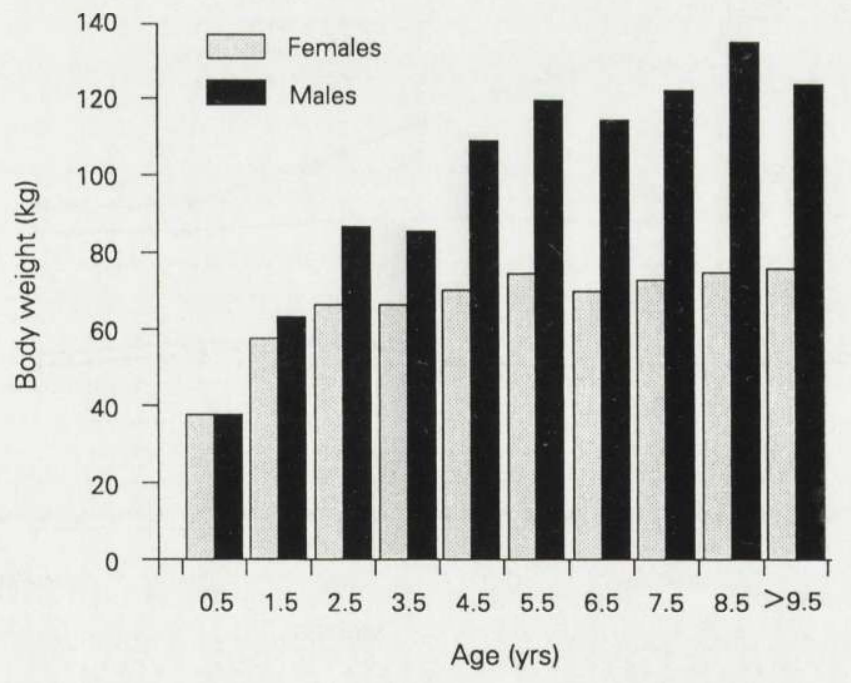

Fig. 1. Relationship between body weight and age in red deer harvested in the Słowiński National Park during years of $1990-1995$. 
years old animals, in which males were significantly heavier than females (one way ANOVA, $p=0.02$ ). In older individuals body weight is stabilized: in hinds at the age of $2.5 \mathrm{yrs}$, while in stags - at the age of $4.5 \mathrm{yrs}$ (Fig. 1). In this connection some age-groups were identified based on dressed body weights. Stags were divided into two age categories: juvenile $-1.5-3.5$ yrs old and adult $-\geq 4.5$ yrs old. Dressed body weight of juvenile stags was significantly lower than adult ones $(p<0.001)$. Body weight increased with age in juvenile stags $(p<0.001)$. Adult stags $(\geq 4.5$ yrs old), which participated in breeding, had slight but not significant increments in body weight and formed uniform group in respect to weight (Fig. 1).

Hinds were divided also into two categories: juvenile hinds 1.5 yrs old, which did not participate in breeding and with dressed body weight significantly different from that of adult hinds $\geq 2.5$ yrs old (one way ANOVA, $p<0.001$ ). In adult hinds participating in breeding, no significant differences in body weight were found with increasing age (Fig. 1).

Deer examined have been harvested during various months of the hunting season from August to February. We found that among calves the dressed body weights of males and females did not differ significantly, but the highest body weights of calves were occurring during November and differ significantly when compared to remaining months (two way ANOVA, $p<0.001$ ). Body weights of hinds harvested during successive months of the hunting season did not vary, on contrary to body weights of stags, for which a significant decline of body weights was found during autumn and winter (Fig. 2). The decline took the shape of straight regression $(y=-9.48+116.06 x, r=-0.97, p<0.001)$.

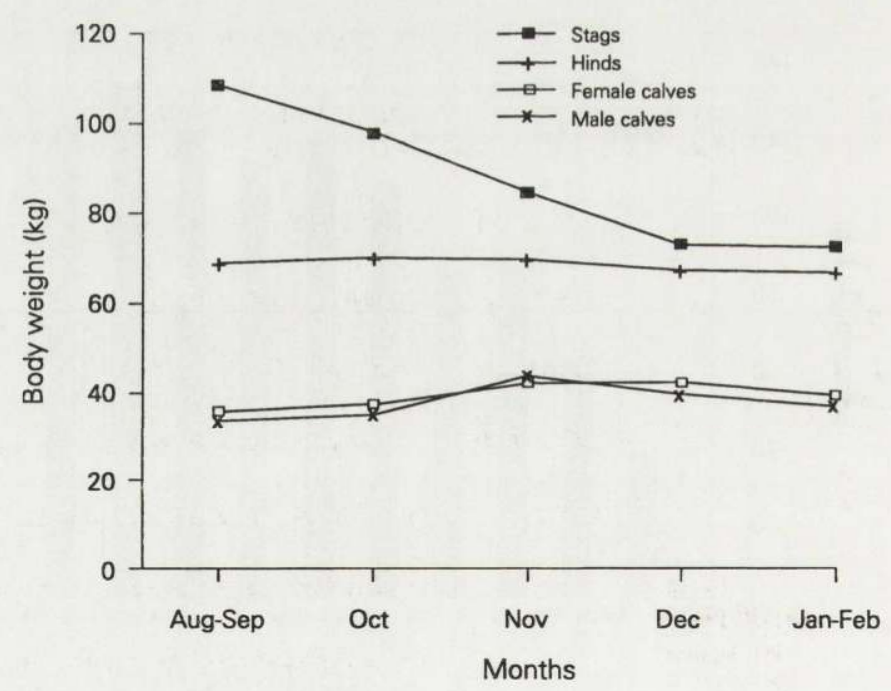

Fig. 2. Body weight of red deer harvested during successive months of the hunting season, during years of 1990-1995. 


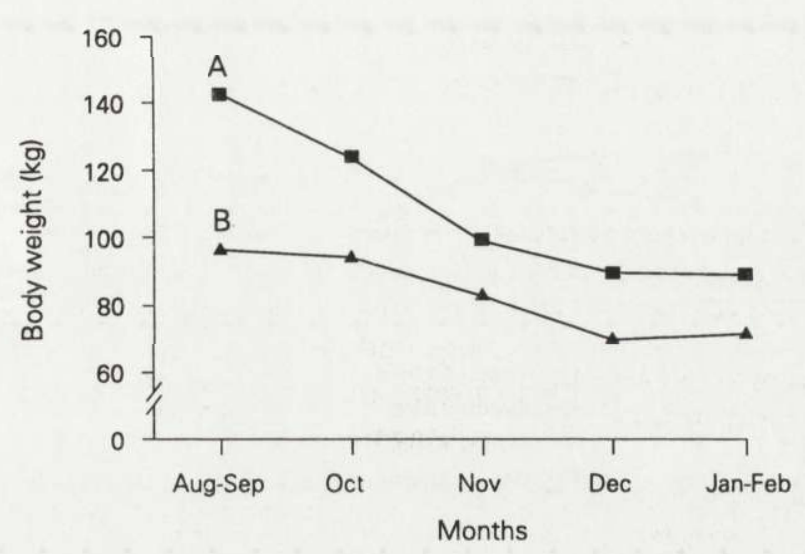

Fig. 3. Seasonal changes in body weight in relation to age of stags (A - stags older than 3.5 years, B - stags 1.5 to 3.5 years old).

It was tested whether the drop in body weight of stags from August until February differed in juvenile (1.5 to 3.5 years old) versus adult ( $\geq 4.5 \mathrm{yrs}$ old) stags. Regression lines, calculated for these two age groups, had the following course: $y=89.17-5.05 x, r=-0.39, p<0.001$ for juvenile stags, $y=155.02-$ $14.76 x, r=-0.70, p<0.001$ for adult stags. Both linear regression lines were not parallel to each other. This was documented by significant differences in values of the $\mathrm{b}$ coefficient in regression equations for both groups (Student's $t$-test, $p<0.001$ ). Decline of body weight in adult stags was more rapid than in juvenile stags (Fig. 3).

\section{Kidney fat index}

Condition of both sexes of calves was inferior to that in older individuals. KFI for female calves was significantly lower than for $\geq 1.5$ yrs old hinds (one way ANOVA, $p=0.03$ ). Similarly, for male calves KFI was lower than that for $\geq 1.5$ yrs old stags $(p \leq 0.001)$.

In the case of females (calves, juvenile and adult hinds) KFI was not subjected to any significant changes from August until February. Similar fact was recorded also for male calves (Fig. 4). Nevertheless female calves had always higher KFI (1.54) than male calves (1.36) and these differences were statistically significant (one way ANOVA, $p=0.003$ ) (Fig. 4 ).

Juvenile stags $1.5-3.5$ years old and adult stags $\geq 4.5$ years old indicated good condition during the rut, ie in August and September (Fig. 4). It was found that at this time the older were stags, the better condition they had. Relationship between stag's age and KFI was significant $(r=0.41, p<0.001)$ and had the form of a linear regression $(y=1.30+0.12 x)$. Following the rut KFI in stags dropped rapidly in October and until February was maintained at the same, low level. Condition decline was more severe in the case of adult than juvenile stags (Fig. 


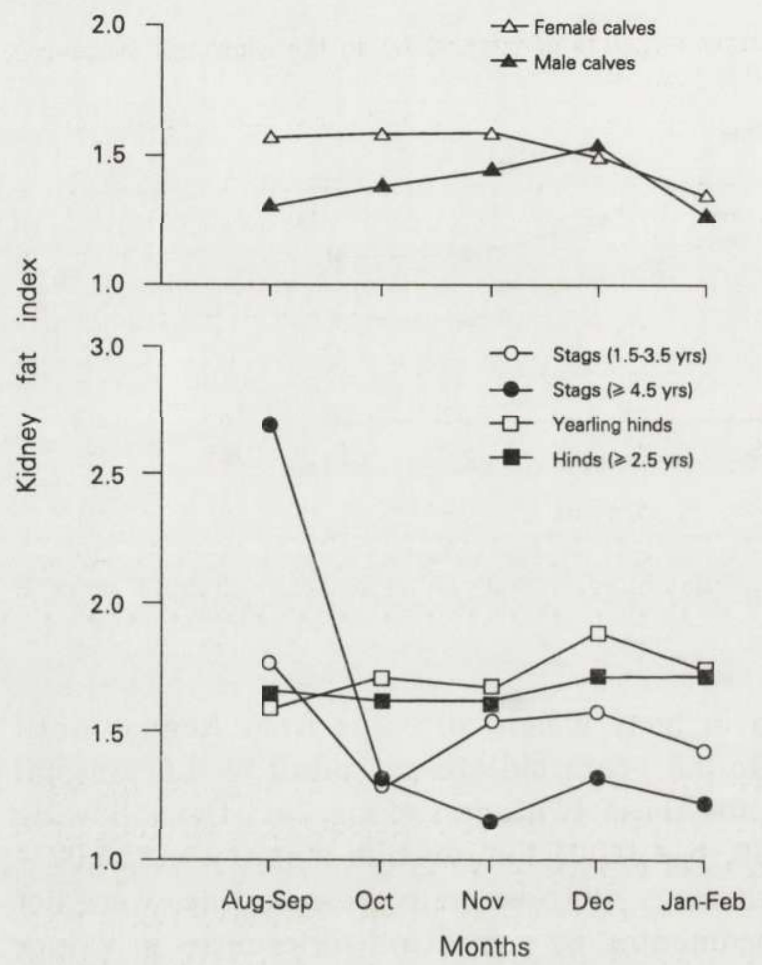

Fig. 4. Seasonal changes in KFI value for red deer in the Słowiński National Park.

4). Differences in KFI during the rut and after it were significant both for juvenile (one way ANOVA, $p<0.001)$ and for adult stags $(p<0.001)$.

In hinds KFI values were maintained during autumn and winter at the same level (Fig. 4). During the rut stags, both juvenile and adult ones, were consistently in better condition than hinds. The situation reversed after the rut (one way ANOVA: $p<0.001$ for juvenile hinds and stags, $p<0.001$ for adult hinds and stags).

Changes in body weights of adult stags ( $\geq 4.5$ years old) during autumn and winter were afterwards compared to changes in KFI values during these seasons. The decline of condition in stags, as measured by both indices was in the shape of straight regression $(y=153.04-14.36 x, r=-0.72, p<0001$ for body weight; $y=2.68-0.35 x, r=-0.48, p<0.001$ for KFI). Deterioration of condition in this group of animals was shown first by the drop in KFI values followed by the decline in body weight. This was found by comparing $b$ coefficient of both straight regressions by $t$-test $(p<0.001)$.

\section{Visceral fat}

Among 623 red deer individuals examined, those devoid of visceral fat were rare. Such cases occured mainly in calves and in stags harvested following the rut 
Table 1. Frequency (\%) of red deer with various amounts of visceral fat in the Słowiński National Park population. ${ }^{*}-1.5-3.5$ years old, ${ }^{* *}-1.5$ year old.

\begin{tabular}{|c|c|c|c|c|c|c|c|c|c|}
\hline \multirow{4}{*}{$\begin{array}{l}\text { Deer } \\
\text { category }\end{array}$} & \multirow{4}{*}{ Sex } & \multicolumn{8}{|c|}{ Months } \\
\hline & & \multicolumn{4}{|c|}{ Aug-Sep (rut) } & \multicolumn{4}{|c|}{ Oct-Feb } \\
\hline & & \multirow{2}{*}{$n$} & \multicolumn{3}{|c|}{$\%$ with definite amount of fat } & \multirow{2}{*}{$n$} & \multicolumn{3}{|c|}{$\%$ with definite amount of fat } \\
\hline & & & lack & low & high & & lack & low & high \\
\hline \multirow[t]{2}{*}{ Calves } & males & 30 & 7 & 60 & 33 & 57 & 10 & 58 & 32 \\
\hline & females & 33 & 12 & 49 & 39 & 52 & 11 & 60 & 29 \\
\hline \multirow[t]{2}{*}{ Juvenile } & males* & 29 & 7 & 45 & 48 & 58 & 5 & 72 & 23 \\
\hline & females** & 21 & 0 & 52 & 48 & 27 & 4 & 41 & 55 \\
\hline \multirow[t]{2}{*}{ Adult } & males & 19 & 0 & 10 & 90 & 35 & 9 & 66 & 25 \\
\hline & females & 105 & 0 & 25 & 75 & 156 & 2 & 37 & 61 \\
\hline
\end{tabular}

(Table 1). Since these animals constituted only $11 \%$ of the total sample, further analyses of condition were carried out while comparing proportions of obviously fat individuals within age classes and sex groups.

During August and September the proportion of obviously fat individuals was the same in both sexes of calves, juvenile and adult deer (Table 1) $(p>0.01$ in all three cases, test for the comparison of two percentages, Bailey 1959). During the winter (October-February) the frequency of obviously fat individuals was higher both among juvenile and adult deer in females than in males $(p<0.001$ for juvenile hinds and stags, $p<0.001$ for adult hinds and stags). On the other hand in the group of calves the proportion of individuals with large amounts of visceral fat was equal in both sexes $(p>0.01)$ (Table 1$)$.

Comparison of the proportions of obviously fat individuals at the beginning and during the latter part of hunting season, indicated that only in stags older than

Table 2. Changes in the proportion of red deer with high reserves of visceral fat in various age-classes.

\begin{tabular}{|c|c|c|c|c|c|c|c|c|c|}
\hline \multirow{3}{*}{$\begin{array}{l}\text { Age- } \\
\text {-class } \\
(\mathrm{yrs})\end{array}$} & \multirow{3}{*}{$\begin{array}{c}\text { Mean } \\
\text { age } \\
\text { (yrs) }\end{array}$} & \multicolumn{4}{|c|}{ Aug-Sep (rut) } & \multicolumn{4}{|c|}{ Oct-Feb } \\
\hline & & \multicolumn{2}{|c|}{ Males } & \multicolumn{2}{|c|}{ Females } & \multicolumn{2}{|c|}{ Males } & \multicolumn{2}{|c|}{ Females } \\
\hline & & $n$ & $\%$ & $n$ & $\%$ & $n$ & $\%$ & $n$ & $\%$ \\
\hline 0.5 & 0.5 & 30 & 33.3 & 33 & 39.4 & 57 & 31.6 & 52 & 32.7 \\
\hline 1.5 & 1.5 & 10 & 30.0 & 21 & 47.6 & 30 & 20.0 & 27 & 55.5 \\
\hline $2.5-3.5$ & 3.0 & 19 & 63.2 & 46 & 71.7 & 29 & 24.1 & 42 & 61.9 \\
\hline $4.5-6.5$ & 5.5 & 9 & 88.9 & 32 & 78.1 & 18 & 33.3 & 52 & 63.5 \\
\hline $7.5-9.5$ & 8.5 & 6 & 83.3 & 16 & 81.2 & 12 & 25 & 27 & 66.7 \\
\hline$\geq 9.5$ & 13.5 & 4 & 100.0 & 12 & 66.7 & 5 & 0 & 34 & 55.9 \\
\hline
\end{tabular}


Table 3. Relationship between condition decline and age in red deer stags in the Słowiński National Park. a1, a2 - percent of individuals with high fat resources during and after rut, $x 1, x 2$ - mean KFI value during and after rut.

\begin{tabular}{|c|c|c|c|c|c|c|}
\hline \multirow{3}{*}{$\begin{array}{l}\text { Age groups } \\
\text { of stags } \\
\text { (yrs) }\end{array}$} & \multicolumn{6}{|c|}{ Condition appraisals } \\
\hline & \multicolumn{3}{|c|}{$\begin{array}{l}\text { According to frequency of individuals with } \\
\text { high fat resources }\end{array}$} & \multicolumn{3}{|c|}{ According to KFI } \\
\hline & a1 & $\mathrm{a} 2$ & $(\mathrm{a} 1-\mathrm{a} 2) \times 100 / \mathrm{a} 1$ & $x 1$ & $x 2$ & $(x 1-x 2) \times 100 / \mathrm{a} 1$ \\
\hline 1.5 & 30.0 & 20.0 & 33.3 & 1.54 & 1.51 & 2 \\
\hline $2.5-3.5$ & 63.2 & 24.1 & 61.9 & 1.88 & 1.42 & 24 \\
\hline $4.5-6.5$ & 88.9 & 33.3 & 68.5 & 2.43 & 1.35 & 44 \\
\hline $7.5-9.5$ & 83.3 & 25.0 & 70.0 & 3.18 & 1.25 & 61 \\
\hline$\geq 10.5$ & 100.0 & 0 & 100.0 & 2.04 & 1.12 & 45 \\
\hline
\end{tabular}

2.5 years significant differences occured (Table 2). The frequency of individuals with remarkable visceral fat reserves decreased markedly following rut in these age-groups of stags $(p<0.001)$. Fractions of obviously fat individuals were similar in juvenile and adult females as well as in calves of both sexes during both periods of time compared (Table 2).

During the rut (August and September) the proportion of obviously fat individuals was positively correlated with age (Table 2). Such a relationship was recorded only in the case of stags $(r=0.94, p<0.01)$ within the range of age from 0.5 to 9.5 years. After the rut, the frequency of obviously fat deer of both sexes was maintained at a uniform level. Fractions of obviously fat individuals were, after all, more numerous among hinds than among stags (Table 2).

It was noted that deterioration of condition following to rut was more severe in older versus juvenile stags (Table 3). This was true both when the condition had been assessed with the aid of KFI and when percentage of fat individuals had been used.

\section{Antler weight}

Antler weight varied significantly with the age of stag. This relationship had the form of a straight regression $(y=0.32+0.40 x, r=0.82, p<0.001)$. It was also examined whether there is any relationship between antler weight, body weight and age of stags. It was found that the variation of antler weight was affected by variation in age and in body weight $\left(R^{2}=0.80\right)$.

\section{Discussion}

Red deer body weight is a good index of condition for populations living in various habitats. Variation in red deer body weights was described in numerous papers both in Poland (Bobek and Kosobucka 1985, Krupka et al. 1986, Bobek et 
al. 1992, Łabudzki 1993) and elsewhere in Europe (Watson 1980, Mitchell and Crisp 1981, Mitchell et al. 1981, Langvatn and Albon 1986).

Several studies indicated seasonal changes in red deer body weights, particularly so in the case of males (Bobek et al. 1989, 1992). Our results confirm the fact of decline in body weights from August until winter. This decline is more pronounced in older stags actively participating in rut when compared to juvenile stags, what was also recorded elsewhere (Bobek et al. 1992).

Comparison of body weight of red deer calves from various regions of Poland revealed that in the SPN mean body weight of calves of both sexes had been remarkably lower $(38.0 \mathrm{~kg})$ than eg in northern and eastern Poland $(44.8 \mathrm{~kg}$; Dzięciołowski 1970) or in the south-east of Poland (48.8 kg; Bobek et al. 1992).

Body weight of male and female calves did not differ significantly in our studies. On the other hand, in Wielkopolska male calves were by far heavier than female ones (Łabudzki 1993). Differences there amounted to $4-29 \%$ of body weights on the favour of males. Under farm conditions male calves were also considerably heavier than female ones (Krzywiński et al. 1980).

Body weight of both juvenile and adult hinds harvested in the study area were similar to those in Wielkopolska (Table 4). On the other hand, the highest body weights were recorded for Carpathian hinds. These varied from 85.2 to $89.7 \mathrm{~kg}$ (Bobek et al.1992).

The mean body weight of stags from various age classes from the SNP varied from 63.2 to $132.4 \mathrm{~kg}$. On the other hand, earlier studies by Dzięciołowski (1969) revealed the mean body weights of red deer stags in similar age classes from lowland regions of Poland from 73.0 to $172.5 \mathrm{~kg}$. This is an indication that red deer from SNP in respect to condition do not deviate from other lowland populations. Data from other regions are not comparable because body weights were given for carcasses without heads and antlers.

While searching after a good indicator of condition status, Franzmann (1992), after 8 years long studies, arrived at the conclusion that body fat was the most important indicator of condition status. Analyses of stag condition during the rut indicated that it is positively correlated with age of stags. Stag's social position

Table 4. Comparison of body weight in hinds. * - after Łabudzki (1993).

\begin{tabular}{|c|c|c|c|c|c|c|}
\hline \multirow{3}{*}{$\begin{array}{l}\text { Age-class } \\
\text { (yrs) }\end{array}$} & \multicolumn{6}{|c|}{ Body wt (kg) } \\
\hline & \multicolumn{3}{|c|}{ Słowiński National Park } & \multicolumn{3}{|c|}{ Wielkopolska* } \\
\hline & Mean & SD & $n$ & Mean & SD & $n$ \\
\hline 1.5 & 57.8 & 7.7 & 48 & 60.7 & 6.8 & 190 \\
\hline $2.5-5.5$ & 69.1 & 8.2 & 149 & 70.3 & 7.0 & 464 \\
\hline $6.5-8.5$ & 73.2 & 9.8 & 62 & 74.5 & 7.1 & 255 \\
\hline$\geq 9.5$ & 75.1 & 13.1 & 50 & 75.7 & 6.5 & 120 \\
\hline
\end{tabular}


and his future reproductive success are related to body and antler mass, and those features to a large extent depend upon individual's age (Clutton-Brock et al. 1982).

Relationship between condition and age, found also in the present research, seems to be a logical consequence of the breeding strategy of stags. Adult stags with heavy antlers have to accumulate adequate energetic reserves to confirm or improve their social status through fights and to achieve a maximum breeding success. Such a positive correlation between body mass during rut in stags and condition (KFI) was found in case of red deer from the Słowiński National Park. With one exception we had no stags older than 10 years. It is, therefore, hard to say whether the relationship between condition and age, found in our study, includes also the group of the oldest males.

The condition of hinds, as measured by KFI during August and September revealed no relationship with age. On the other hand, analyses of frequencies of females with a large amount of visceral fat indicate relationship between the proportion of fatty hinds and their age (Table 2). This relationship is obvious up to the age of $9.5 \mathrm{yrs}$. In the group of hinds older than $10 \mathrm{yrs}$ a decrease of frequency of fat individuals has been noted. It may result from senile alterations in condition, but small size of the sample precluded a statistical verification of this supposition.

Our studies indicated that stags, contrary to hinds, are as a sex subjected to sharp changes of condition during autumn and winter, ie post-rut season. In the case of the population studied the decline of stag's condition was recorded both by the KFI and by the comparison of proportions of animals with high fat deposits during the rut and after it.

Rapid changes in male body weight recorded during the hunting season are also a symptom of condition decline. From the comparison of changes in body mass and KFI values in the group of adult stags it results that deterioration of condition is manifested first by a decline in visceral fat level and only afterwards by the decline in body weight. Condition decline in stags following the rut is well documented (Clutton-Brock et al. 1982).

A significant finding of the present studies was the fact that the decline of condition had been related to the age of stags. This decline was deepest in the oldest age-group analysed by us (Table 3). Obviously females manage their fat reserves more rationally, which was indicated by lack of differences in KFI, visceral fat and body weight values during and after rut.

The condition of calves was in both sexes maintained at a roughly equal level, although at the begining of the hunting season (August and September) males were in poorer condition than females. It is evidenced by significant differences in KFI values in both sexes. The inferior condition of male calves is also suggested by the lack of differences in their body weights when compared to that of female calves. Greater mortality of male calves may be related to their poor condition (Buchli 1979).

Calves of both sexes were, as growing individuals, in poorer condition than the older individuals. During August and September the condition of male calves was 
Table 5. Comparison of antler's weight $(\mathrm{kg})$ in stags from the Słowiński National Park, Wielkopolska and Lublin Province.

\begin{tabular}{cccc}
\hline $\begin{array}{c}\text { Age } \\
\text { (yrs) }\end{array}$ & $\begin{array}{c}\text { Slowiński } \\
\text { National Park }\end{array}$ & $\begin{array}{c}\text { Wielkopolska } \\
\text { (Labudzki 1993) }\end{array}$ & $\begin{array}{c}\text { Lublin Province } \\
\text { (Krupka et al. 1986) }\end{array}$ \\
\hline 1.5 & 0.6 & 0.7 & 0.4 \\
2.5 & 1.5 & 1.5 & 1.6 \\
3.5 & 1.5 & 2.0 & \\
4.5 & 2.5 & 2.6 & 3.2 \\
5.5 & 3.1 & 2.7 & \\
6.5 & 2.9 & 3.0 & \\
7.5 & 3.5 & 3.5 & \\
8.5 & 3.7 & 4.0 & \\
9.5 & 4.5 & 4.5 & \\
$\geq 9.5$ & 4.2 & 4.8 & \\
\hline
\end{tabular}

lower than that of juvenile and adult stags. This was evidenced by differences in KFI values and by the comparison of proportions of individuals with high fat reserves. In the case of female calves significant differences were also found in KFI values between them and juvenile or adult hinds. This is also confirmed by the frequency of individuals with high fat reserves which was lowest in this group from among all the identified female age-groups (Table 2).

In the course of present studies we found a significant relationship between antler and body weights in stags, what confirmed earlier data (Clutton-Brock et al. 1982). The quality of antlers of stags from the SNP was comparable to that of stags from lowland regions of Poland (Table 5).

Population density may affect physical condition of individuals through: (1) increase in competition for food, (2) increase in frequency of antagonistic encounters between individuals (mainly among stags during rut), and (3) increase in parasitic infestation (Clutton-Brock et al. 1982). We did not carry out research on the food carrying capacity of habitats in the Słowiński National Park. From direct observations it results, however, that local deer utilized not only food gathered in forests, but to a large extent exploited also meadows,pastures, and farm crops neighbouring their diurnal retreat. This fact undoubtedly relieves, if not eliminates entirely the competition for food.

Antagonistic contacts among individuals were not studied either. Nevertheless, based on our studies, one may assume that this factor should affect condition of males under conditions of high population density. It is because we found that males participating in rut indicated thereafter a particularly severe decline of condition.

Parasitological research on red deer from the Słowiński National Park that was carried out paralelly to our studies, brought some interesting findings. Nematodes occurred in the abomasa of all the individuals. Fifteen species of helminths were 
found, so the list of parasite species is rather short (Dróżdż et al. 1993). So, the very high density of red deer population did not contribute to any increase of infection of these animals by helminths. These findings well corroborate the generally good condition of animals found in the course of this study. It is also concurrent with results obtained by Buchli (1979) for a high density red deer population in Switzerland.

In the course of a remarkable reduction of red deer population Mitchell and Crisp (1981) studied the level of animal performance at exceptionally high population density and checked for changes in performance after the culling. Contrary to expectations, the general level of performance was not unusually low and there was no evidence of excessive parasitic infestation. Following the reduction down to $20 \%$ of their previous numbers the animals surprisingly showed no improvements in performance.

Negligible if any, competition for food and relatively low level of parasitic infestation of the SNP red deer population may explain their rather good condition. These factors may be the reason of the fact that, in spite of a very high density, individuals in the studied population do not deviate in body weight, fat reserves from other red deer populations in lowlands of Poland (Dzięciołowski 1970).

Acknowledgements: Authors wish to acknowledge the financial support of the Committee of Scientific Research (grant No 501309 21) and Forest Service USDA (grant No PL-FS-97).

\section{References}

Albon S. D., Mitchell B. and Staines B. W. 1983. Fertility and body weight in female red deer: a density-dependent relationship. Journal of Animal Ecology 52: 969-980.

Bailey N. T. J. 1959. Statistical methods in biology. The English Universities Press LTD, London: 1-200.

Bertouille S. B. and de Crombrugghe S. A. 1995. Body mass and lower jaw development of the female red deer as indices of habitat quality in the Ardennes. Acta Theriologica 40: 145-162.

Bobek B. and Kosobucka M. 1985. Modelling of the population dynamics and structure in red deer (Cervus elaphus) in southeastern Poland. Proceedings of the 17th International Union of Game Biologists Congress. Brussels, Belgium: 173-180.

Bobek B., Morow K., Perzanowski K. and Kosobucka M. 1992. The red deer (Cervus elaphus) - its ecology and management. Swiat Publisher, Warszawa: 1-220. [In Polish with English contents, table titles and captions for figures]

Bobek B., Perzanowski K. and Weiner J. 1989. Energy expenditure for reproduction in male red deer. Journal of Mammalogy 71: 230-232.

Buchli C. 1979. Populationsdynamik, Kondition und Konstitution des Rothirsches (Cervus elaphus L.) im und um den Schweizerischen Nationalpark. Habilitierung Dissertation, St. Gallen, Zurich: 1-99.

Cheatum E. L. and Severinghaus C. W. 1950. Variations in fertility of white-tailed deer related to range conditions. Transactions of North American Wildlife and Natural Resources Conference 15: $170-189$.

Clutton-Brock T. H., Guinness F. E. and Albon S. D. 1982. Red deer. Behavior and ecology of two sexes. Edinburgh University Press, Edinburgh: 1-378. 
Clutton-Brock T. H., Major M., Albon S. D. and Guinness F. E. 1987. Early development and population dynamics in red deer. 1. Density-dependent effects on juvenile survival. Journal of Animal Ecology 56: 53-67.

Dróżdż J., Demiaszkiewicz A. W. and Lachowicz J. 1993. Seasonal changes in the helminth fauna of Cervus elaphus (L.) from Słowiński National Park (Poland). Acta Parasitologica 38: 85-87.

Dzięciołowski R. 1969. [Weight of our red deer from lowlands]. Łowiec Polski 19: 5-6. [In Polish]

Dzięciołowski R. 1970. Relations between the age and size of red deer in Poland. Acta Theriologica 15: 253-268.

Dzięciołowski R., Goszczyński J., Wasilewski M. and Babińska-Werka J. 1995a. Numbers of red deer in the Słowiński National Park, Poland. Acta Theriologica 40: 45-51.

Dzięciołowski R., Wasilewski M., Goszczyński J. and Babińska-Werka J. 1995b. Occurrence of lactation in red deer Cervus elaphus. Acta Theriologica 40: 295-301.

Franzmann A. W. 1992. Assesment of condition status as a management tool for big game. [In: Global trends in wildlife management. B. Bobek, K. Perzanowski and W. Regelin, eds]. Transactions of the 18th Congress of International Union of Game Biologists, Kraków 1987. Swiat Press, Kraków-Warszawa: 199-201.

Krupka J., Dziedzic R. and Drozd L. 1986. [Quantitative characteristics of red deer stags culled in central-eastern Poland]. Annales Universitatis Mariae Curie-Skłodowska, Lublin 4: 1-5. [In Polish]

Krzywiński A., Krzywińska K., Kisza J., Roskosz A. and Kruk A. 1980. Milk composition, lactation and the artifical rearing of red deer. Acta Theriologica 25: 341-247.

Langvatn R. and Albon S. D. 1986. Geographic declines in body weight of Norvegian red deer: a novel explanation of Bergmann's rule. Holarctic Ecology 9: 285-293.

Łabudzki L. 1993. Characteristics of selected biometric features of red deer (Cervus elaphus L.) in Wielkopolska. Roczniki Akademii Rolniczej, Rozprawy Naukowe 241: 1-59. [In Polish with English summary]

Mc Cullough D. R. 1979. The George Reserve deer herd. Population ecology of a k-selected species. University of Michigan Press, Ann Arbor, JM.

Mitchell B. 1967. Growth layers in dental cement for determining the age of red deer (Cervus elaphus L.). Journal of Animal Ecology 36: 279-293.

Mitchell B. and Crisp J. M. 1981. Some properties of red deer (Cervus elaphus) at exceptionally high population-density in Scotland. Journal of Zoology, London 193: 157-169.

Mitchell B., Grant W. and Cubby J. 1981. Notes on the performance of red deer, Cervus elaphus, in a woodland habitat. Notes from the Mammal Society 42: 279-284.

Mitchell B., Mc Cowan D. and Parish T. 1986. Performance and population dynamics in relation to management of red deer Cervus elaphus at Glenfeshie, Invernesshire, Scotland. Biological Conservation 37: 237-267.

Pielowski Z., Kamieniarz R. and Panek M. 1993. [Report about game animals in Poland]. Państwowa Inspekcja Ochrony Środowiska, Warsaw: 1-129. [In Polish]

Ratcliffe P. R. 1984. Population dynamics of red deer (Cervus elaphus L.) in Scottish commercial forests. Proceedings of the Royal Society of Edinburgh 82B: 291-302.

Shea S. M., Breault T. A. and Richardson M. L. 1992. Herd density and physical condition of white-tailed deer in Florida flatwoods. Journal of Wildlife Management 56: 262-267.

Teer J. G. 1984. White-tailed deer population management: Lessons from the Llano Basin, Texas. [In: White-tailed deer: ecology and management. L. K. Halls, ed]. Stackpole Books, New York: 261-242.

Watson A. 1980. Climatic and the antler-shedding and performance of red deer in north-east Scotland. Journal of Applied Ecology 8: 53-68.

Vincent J. P., Bideau E., Hevison A. J. M. and Angibault J. M. 1995. The influence of increasing density on body weight, kid production, home range and winter grouping in roe deer (Capreolus capreolus). Journal of Zoology, London 236: 371-382.

Received 25 April 1994, revised 12 December 1995, accepted 15 January 1996. 